\title{
Analysis of Physical Parameters of Limestone Deposits in Ewekoro Formation, Southwestern Nigeria
}

\author{
Oluwaseun T. Olurin $^{1}$, B. S. Badmus ${ }^{1}$, O. D. Akinyemi ${ }^{1}$, J. A. Olowofela ${ }^{1}$, V. C. Ozebo ${ }^{1}$ \& S. A. Ganiyu ${ }^{1}$ \\ ${ }^{1}$ Department of Physics, University of Agriculture, Abeokuta, Ogun State, Nigeria \\ Correspondence: Oluwaseun T. Olurin, Department of Physics, University of Agriculture, Abeokuta, P.M.B \\ 2240, Ogun State, Nigeria. Tel: 234-806-660-0703. E-mail: olurin@physics.unaab.edu.ng \& \\ stolurin@yahoo.com
}

Received: March 6, 2012 Accepted: March 21, 2012 Online Published: June 19, 2012

doi:10.5539/esr.v1n2p117 URL: http://dx.doi.org/10.5539/esr.v1n2p117

\begin{abstract}
Physical parameters of limestone in Ewekoro formation, south-western Nigeria were determined via direct laboratory method. The permeability and bulk density values obtained range from 1.47 to $7.99 \mathrm{~ms}^{-1}$ and 1.26 to $1.90 \mathrm{gcm}^{-3}$ respectively. The resistivity values of the limestone samples collected from the study site were obtained by laboratory direct method and the result revealed that the resistivity values fall within 6 and $171 \mathrm{k} \Omega \mathrm{m}$. These values correlate favorably with the results obtained from electrical resistivity method of geophysical prospecting of the study area. The two approaches showed a good degree of correlation in the resistivity value of the limestone and their varying qualities. This research work further showed the occurrence of vast deposit of limestone, which can be of economic importance in mining and for industrial purposes.
\end{abstract}

Keyword: bulk density, limestone, permeability and resistivity

\section{Introduction}

Mineral exploration work was carried out to analyse the physical parameters of limestone in Ewekoro formation. This geophysical exploration was carried out to map the limestone deposit of Ewekoro formation, southwestern Nigeria using direct laboratory method via direct current power supply. This direct method approach is to complement and compare the study carried out by Badmus and Ayolabi (2005) where limestone of Ewekoro formation was delineated using Schlumberger electrode array to map both vertical and lateral extents of the deposit (Figure 1). This approach would also confirm the accuracy of electrical resistivity method of geophysical prospecting for mineral exploration as well as characterizing the various litho-facies of Ewekoro limestone (Badmus \& Ayolabi, 2005). Badmus et al. (2006) carried out geoelectric evaluation of mica schist deposit of Area J4, southwestern, Nigeria using the direct laboratory method to characterize the mica schist into different degrees of purity for both economic and commercial purposes. Several studies have also been carried out to evaluate the distribution of limestone deposits at Ewekoro quarry. Adegoke et al. (1970) subdivided the limestone deposits into three units. Omatosola and Adegoke (1981) then proposed a fourth unit. These units in stratigraphic order are: sandy biomcrosparite (bottom), shelly biomcrite, algal biosparite and red phosphate biomcrite (top). The sandy biomcrosparite forms the base of the formation and consists of a light brown sandy limestone with very few bioclassic fragments. Stratification is evident and is accentuated by variations in the quantity and grain size of the interbedded quartz and glauconite. The shelly biomcrite consists of pure limestone of about 4.5 to $6.0 \mathrm{~m}$ and constitute the bulk of the Ewekoro formation in the quarry. Limestone has abundant macrofossil content particularly gastropods, pelecypods, echinoderms and corals. The algal biosparite limestone overlies the shelly biomcrite unit. Resistivity is the only electrical characteristic of geoelectric property. Most rock forming minerals have conductivities spreading over a wide range and are semiconductors. However, these rocks are seen as insulators in their dried form. The amount of moisture contained in the rock depends on the structure especially the amount of pore space and cracks. Rocks and sediments contain space between grains (pore space) in fractures or in dissolved cavities (limestone), which may be filled with water. Isolating the drain from the atmosphere can lead to an increase of the partial pressure of carbon dioxide within the system and to an increase of the dissolution rate of calcite. More importantly, it also minimizes the potential for oxidation of $\mathrm{Fe}^{2+}$ (to $\mathrm{Fe}^{3+}$ ) and the risk of precipitation of $\mathrm{Fe}(\mathrm{OH})_{3}$ and of other related solids in the drain. Formation of these precipitates can result in premature drain failure due to limestone armouring, which can significantly reduce the 
rate of calcite dissolution and affect the flow. The presence of $\mathrm{Al}^{3+}$ within the influent is also of concern; $\mathrm{Al}(\mathrm{OH})_{3}$ is formed at a pH between 4 and 5 and it tends to accumulate in pores, thus potentially clogging the voids and consequently reducing the material hydraulic conductivity Poirier and Aubertin (2011). The porosity and chemical content of the water filling the pore spaces are more important in governing resistivity than conductivity of the mineral grains of which the rock is composed. The resistivity curves are deflected towards high levels with positive separation. The glauconite is prevailing in these intervals. The limestone of this formation is dolomitic, sandy and shaly in parts. In some limestone intervals, the glauconite is present. The marl is light gray, silty, calcareous and grading to limestone Ghorab (2010). Limestone is a raw material for the manufacturing of cement, asphalt filler, ceramics, flux in glass making, fertilizer filler, explosives to mention just a few. Jones and Hockey (1964) revealed Ewekoro limestone and the overlying Akinbo shale to be lateral equivalents of the Imo formation of eastern Nigeria. Other authors such as Omatsola and Adegoke (1991) and Oladeji (1992) have investigated the stratigraphy and depositional characteristics of limestone and clay/shale deposits in southwestern Nigeria. The West African Portland Cement Company also conducted extensive geological survey and commercial appraisal of Ewekoro limestone and shale beds for commercial cement production.

\section{Study Area}

The study area lies within Ogun State, which is bounded in the west by Benin Republic, in the south by Lagos State, in the north by Oyo and Osun States, and in the east by Ondo State. It occupies a total area of. Ewekoro is the host to West African Portland cement quarry and lies between longitude $3^{\circ} 05^{\prime} \mathrm{E}$ to $3^{\circ} 15^{\prime} \mathrm{E}$ and latitudes $6^{\circ} 40^{\prime} \mathrm{N}$ to $6^{\circ} 55^{\prime} \mathrm{N}$ (Figure 2).

\section{Geology of the Study Area}

The study area is located in the sedimentary area of southwestern Nigeria. Ewekoro formation belongs to tertiary-formed Palaeocene and Eocene; and the greater part of the depression is a potential artesian basin where ground water can be sourced. Adegoke et al. (1976) outlined the Albran and younger Palaeographic history of Nigeria and summarized the nature and extent of transgressive, regressive phases as well as the nature of the sediment. The geology of Ogun State comprises sedimentary and basement complex rocks, which underlie the remaining surface area of the state. It also consists of intercalations of argillaceous sediment. The rock is soft and friable but in some places cement by ferruginous and siliceous materials. The sedimentary rock of Ogun State consists of Abeokuta formation lying directly above the basement complex (Figure 2). Ewekoro, Oshosun and Ilaro formations in turn overlie this, which are all overlain by the coastal plain sands (Benin formation).

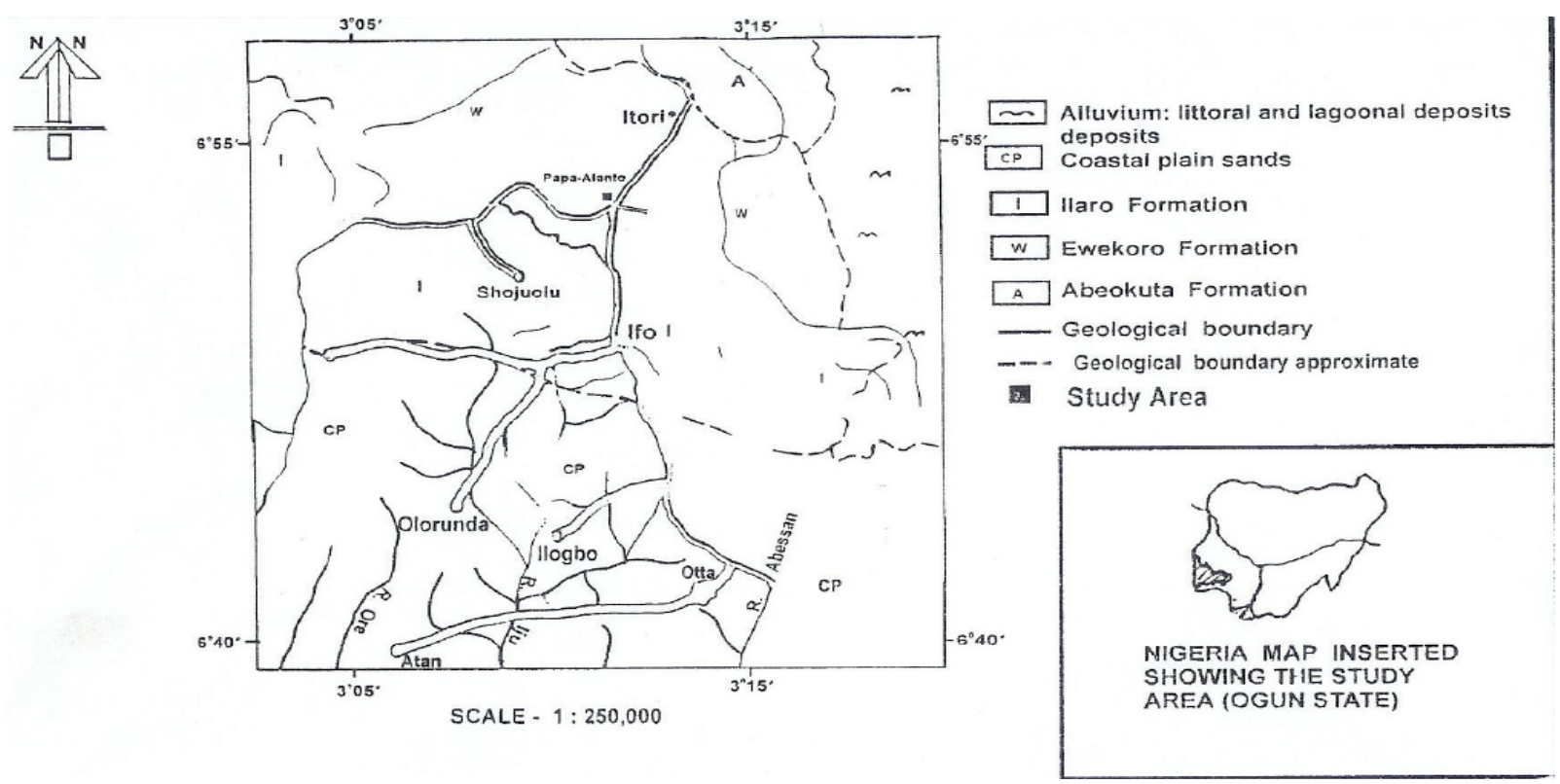

Figure 1. Geological map of Papa-Alanto and its environ (Bulletin: Geological Survey, Nigeria, No. 31, R. D. Hockey, H. A. Jones and J. D. Carter, 1957-61) 


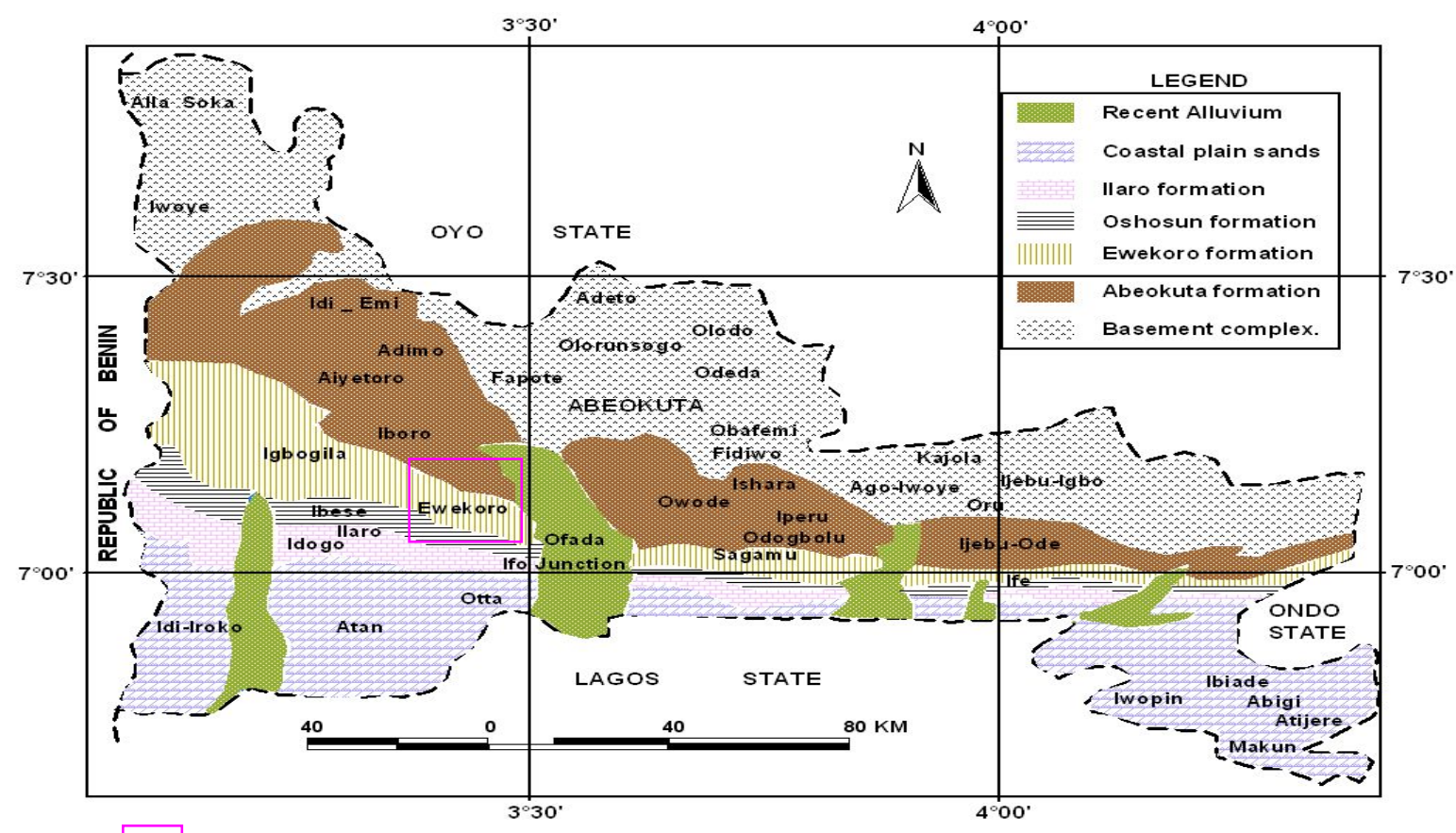

Study Area

Figure 2. Geological map of Ogun State showing the study area

\section{Methods}

\subsection{Direct Laboratory Measurement Using D.C Supply}

Eight different samples were collected from different location from the study area. Resistivity of limestone sample collected from the study area were analysed using a simple laboratory experimental set-up (Figure 3). The limestone samples collected were packed into a core sampler of cylindrical shape and saturated hydraulically for $24 \mathrm{~h}$. After which they were dried in the oven to remove completely the water content in the samples and were shaped into regular forms so as to make good contact with the pins (connecting wires) inserted into the samples. Direct current source was used to supply voltage across the two ends of the core sampler. Voltage was supplied at 12 and $24 \mathrm{~V}$ and the corresponding currents were recorded respectively (Table 1).

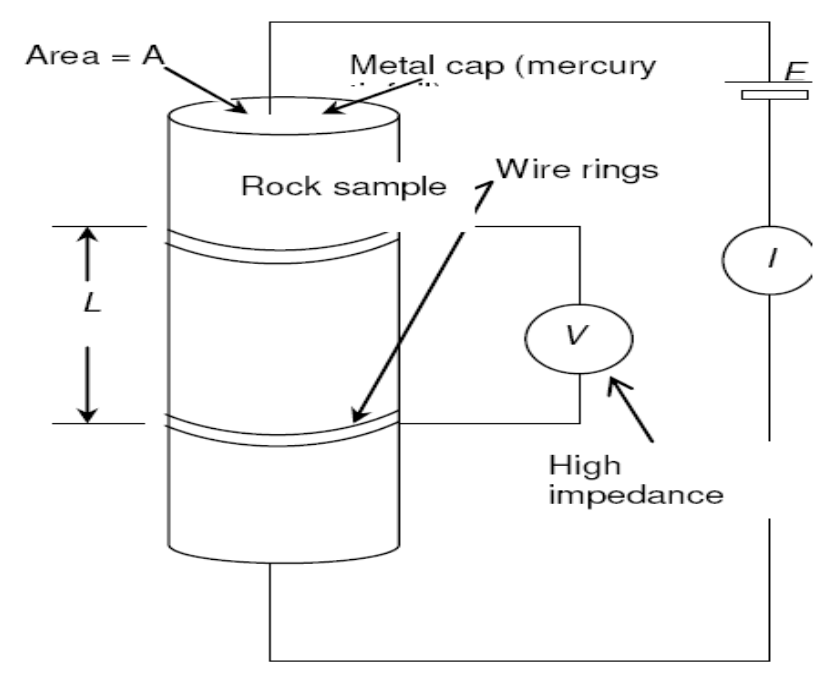

Figure 3. Direct method experimental setup 


\section{Results and Discussions}

Table 1 and 2 shows the resistivity values, permeability values and bulk density as obtained from the simple laboratory direct measurement using a direct current supply of 12 and $24 \mathrm{~V}$. The resistivity values range between $6.2 \mathrm{k} \Omega \mathrm{m}-171.2 \mathrm{k} \Omega \mathrm{m}$ at $12 \mathrm{~V}$ supply and $6.2 \mathrm{k} \Omega \mathrm{m}-164.4 \mathrm{k} \Omega \mathrm{m}$ at $24 \mathrm{~V}$.

For the resistivity measurements, there is no significant difference between the values obtained for all the rock samples collected. However, all rock samples revealed a significant difference for both permeability and bulk density values. For hydraulic conductivity, the formula below was used:

$$
K_{\text {sat }}=\frac{V L}{A T D}
$$

Where:

Area $=\pi r^{2}$

$\mathrm{r}=$ radius of the core sampler

$\mathrm{V}=$ volume of water that passes the sample within 3 minutes

$D=L+H$

$\mathrm{L}=$ length of sample inside the core sampler

$\mathrm{H}=$ length of water from the top of the sample inside the core sampler

$\mathrm{T}=$ time of water run off

$K_{\text {sat }}=$ Saturated hydraulic conductivity

Table 1. Resistivity obtained from direct laboratory measurement

\begin{tabular}{ccc}
\hline Sample Type & $\begin{array}{c}\text { Resistivity }(k \Omega-m) \\
\text { At } 12 \mathrm{~V}\end{array}$ & $\begin{array}{c}\text { Resistivity }(k \Omega-m) \\
\text { At } 24 \mathrm{~V}\end{array}$ \\
\hline A & 15.41 & 15.62 \\
B & 97.60 & 97.40 \\
C & 171.23 & 164.38 \\
D & 11.82 & 12.33 \\
E & 14.90 & 14.79 \\
F & 6.10 & 6.10 \\
G & 35.62 & 35.78 \\
H & 44.18 & 43.97 \\
\hline
\end{tabular}

Table 2. Results of Permeability and Bulk Density obtained from direct laboratory measurement

\begin{tabular}{ccc}
\hline Sample Type & $\begin{array}{c}\text { Permeability } \\
\left(\mathrm{ms}^{-1} \times 10^{-6}\right)\end{array}$ & $\begin{array}{c}\text { Bulk Density } \\
\left(\mathrm{gcm}^{3}\right)\end{array}$ \\
\hline A & 2.34 & 1.71 \\
B & 6.67 & 1.50 \\
C & 7.99 & 1.26 \\
D & 1.60 & 1.44 \\
E & 1.79 & 1.30 \\
F & 1.47 & 1.35 \\
G & 4.47 & 1.90 \\
H & 4.64 & 1.40 \\
\hline
\end{tabular}

Badmus and Ayolabi (2005) already characterized the limestone into various litho-facies on the basis of resistivity variations; which is now correlated with the results obtained from the direct laboratory measurement. From this result, samples B and C are characterized as facie I because of their high values of permeability as well 
as resistivity. Sample G and H belong to facie II, which revealed limestone with high compaction and of low economic quality (Table 1).

Samples A, D and E belong to facie III because the resistivity and permeability values revealed that the limestone here is porous with grains as confirmed by Badmus and Ayolabi (2005). While sample F belongs to facie IV with the lowest value of resistivity and highest value for permeability. The limestone here is confirmed to be highly porous with cracks of different degrees.

\section{Conclusion}

The resistivity values of limestone rock samples collected from different location within the study area has revealed by the simple laboratory set up using DC source of 12 and $24 \mathrm{~V}$ showed that the limestone of Ewekoro formation has various degrees of qualities as characterized by their resistivity and permeability values. This research work also showed to certain extents the accuracy of the electrical resistivity method of geophysical prospecting when compared with the results obtained in the work of Badmus and Ayolabi (2005). This research work further showed the occurrence of vast deposits of limestone, which can be of economic importance in mining and industrial purposes.

\section{References}

Adegoke, O. S., Dessauvagie, T. F. J., \& Kogbe, C. A. (1972). Radioactive age determination of glauconite from the type locality of the Ewekoro Formation. Conf. Afr. Geol. Ibadan (1970), 277-280.

Adegoke, O. S., Dessauvagie, T. F. J., Kogbe, C. A., \& Ogbe, F. G. A. (1971). Type section, Ewekoro Formation, biostratigraphy and microfacies. $4^{\text {th }}$ African Micropal. Coll. Abidjan (1970), 37-39.

Adegoke, O. S., Ogbe, F. G. A., \& Jan Du Chene, R. E. (1976). Excursion to the Ewekoro quarry (Paleocene-Eocene). Geol. Guide Nigerian Cretaceous-Recent Loc., 1-17.

Badmus, B. S., \& Ayolabi, E. A. (2005). Litho-facies changes in Ewekoro limestone using Schlumberger geoelectric sounding techniques. J. Appl. Sci. Technol., 10(1\&2), 42-52.

Badmus, B. S., Ayanda, J. D., \& Popoola, I. O. (2006). Geoelectric evaluation of Mica Schist deposits in Area J4 of Southwest, Nigeria. J. Appl. Sci. Technol., 11(1\&2), 39-43.

Ghorab, M. (2010). The Petrol characteristics and their effect on the reservoir for Mheiherrat formation at central part of the Gulf of Suez, Egypt. (Egyptian Petroleum Research Institute)

Jones, H. A, \& Hockey, R. D. (1964). The geology of parts of Southwestern Nigeria. Geol. Survey Nig. Bull, 31, $22-24$.

Kogbe, C. A. (1976). The Cretaceous and Paleogene sediments of southern Nigeria. In C. A. Kogbe (Ed.) Geology of Nigeria, 325-334.

Ojelabi, E. A., Badmus, B. S., \& Salau, A. A. (2002). Comparative Analysis of Wenner and Schlumberger Methods of Geoelectric Sounding in subsurface delineation and groundwater exploration-a case study. $J$. Geol. Soc. India, 60, 623-628.

Oladeji, B. O. (1992). Environmental analysis of Ewekoro Formation at the Shagamu Quarry. Nig. J. Min. Geol., 28(1), 148-156.

Omatsola, M. E., \& Adegoke, O. S. (1981). Tectonic Evaluation and cretaceous stratigraphy of the Dahomey Basin. J. Min. Geol., 5(2), 78-83.

Poirier, C., \& Aubertins, M. (2011). A numerical investigation of physical parameters influencing saturated flow in limestone drains. Paper presented at Securing the future and 8th ICARD, June 23-26, 2009, Skelleftea, Sweden. 